\title{
State Budget Crises: Cause and Effect
}

\author{
Thomas A. Garrett
}

S tate tax revenue grew markedly during the 1990s as a result of rapid economic growth. Burgeoning tax revenues, the resulting budget surpluses, and rosy revenue forecasts prompted almost every state to enact large permanent tax cuts. Ten states enacted cuts of between 1 and 3 percent of total tax revenues, while 33 states enacted cuts in excess of 3 percent of total tax revenues. ${ }^{1}$ According to the Center on Budget and Policy Priorities, the tax cuts of the 1990s reduced actual state tax revenues by 8.2 percent from what they otherwise would have been. Nevertheless, actual tax revenues continued to grow throughout the 1990s, thanks to the economic boom.

It turned out, however, that states financed permanent tax cuts with the temporary economic boom of the 1990s. In contrast to the 1990-91 recession, when nearly every state raised taxes in response to budget shortfalls, fewer than 20 states have raised taxes since the 2001 recession. And in most cases, the tax increases have focused on relatively narrow and/or shrinking tax bases, such as retail sales and cigarettes. ${ }^{2}$ Slow economic growth, a weak stock market, an increase in homeland security responsibilities, and a greater reliance on weakening tax bases continue to prolong states' budget crises.

An important question is whether current budget deficits are due entirely to a reduction in revenue, or whether state expenditures have grown at unusually high rates over the past decade. Annual real per capita state expenditures and revenues from 1970 to 2002 are shown in the figure along with recessions as determined by the National Bureau of Economic Research. ${ }^{3}$ The aggregate state budget deficit is clearly seen at the far right of the figure and is much greater than the deficit associated with the 1990-91 recession. Also, as shown, the growth in real per capita expenditures during the 1990s was not greater than that of earlier decades. In fact, the average annual growth in real per capita state expenditures from 1992 through 2000 was 1.4 percent, compared with 2.5 and 2.3 percent in non-recession years during the 1980s and 1970s, respectively.

However, revenue and expenditure data for the past three years reveal that expenditure growth did not slow in the wake of decreasing tax revenues. Real per capita state revenue fell by 0.2 percent in 2000, 1.9 percent in 2001, and 0.7 percent in 2002 , whereas real per capita expenditures rose by 1.3 percent, 3.4 percent, and 1.3 percent, respectively. While this scenario occurred during other recessionary periods, as shown in the

figure, state budget surpluses prior to this recent recession were smaller than those prior to earlier recessions, thus increasing the chances that a reduction in revenue would lead to a budget deficit.

States might have underestimated how volatile their revenue sources would prove to be in the face of a recession. States began relying on capital gains and income from stock options and bonuses as a growing source of tax revenue (compared with ordinary earned income). These tax bases are more significantly affected by business cycle and stock market fluctuations. Thus, states with a highly progressive income tax structure, such as California, inadvertently exposed their budgets to the cyclical volatility of capital gains and income from stock options and bonuses.

\footnotetext{
${ }^{1}$ See Johnson, Nicholas. "The State Tax Cuts of the 1990s, the Current Revenue Crisis, and Implications for State Services." Center on Budget and Policy Priorities, November 2002. http://www.cbpp.org/11-14-02sfp.htm.

${ }^{2}$ For a discussion of structural problems in state finance see Knight, Brian; Kusko, Andrea and Rubin, Laura. "Problems and Prospects for State and Local Governments." State Tax Notes, 11 August 2003.

${ }^{3}$ Data are from the Office of Management Budget (http://www.whitehouse.gov/omb/budget/fy2004/hist.html).
}

\section{Real Per Capita State Revenue and Expenditures, 1970 to 2002}

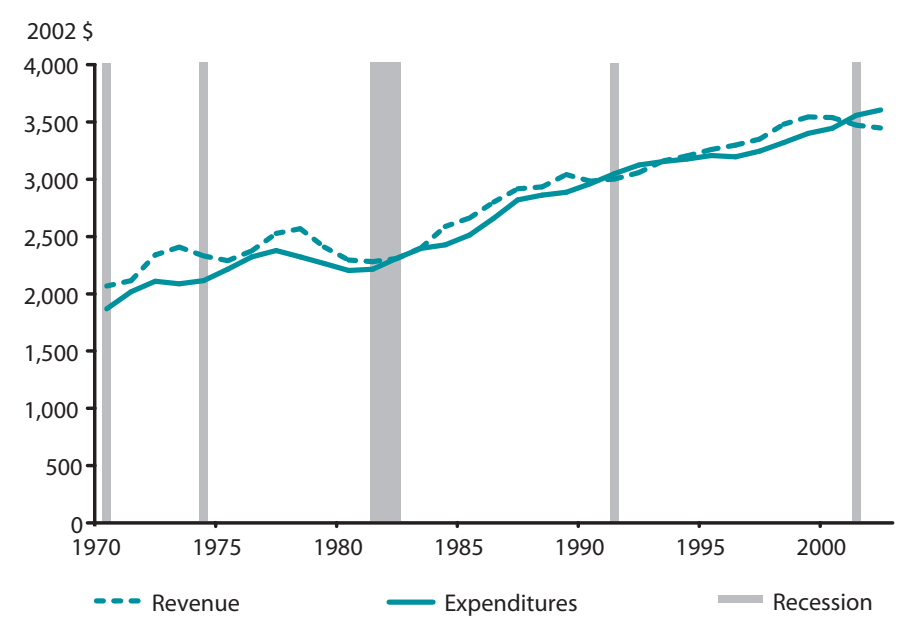

